胃癌に扮ける laminin の免疫組織学的検討

一組織型抢よび転移と laminin との関連一

\author{
近畿大学医学部第 1 外科 \\ 松田泰次坂口隆啓肥田 仁一年隆一 \\ 田中晃赤埴吉高 安富 正幸

\section{IMMUNOHISTOLOGICAL STUDY ON LAMININ IN GASTRIC CANCER IN RELATION TO HISTOLOGICAL TYPE AND METASTASIS} \\ Taiji MATSUDA, Takahiro SAKAGUCHI, Jinichi HIDA, \\ Ryuichi KUBO, Akira TANAKA, Yoshitaka AKABANE \\ and Masayuki YASUTOMI \\ The 1st Department of Surgery, Kinki University School of Medicine
}

胃癌切除例214例を対象とし, formarin 固定 paraffin 切片について, avidin-biotin peroxidase complex 法による laminin 染色を行い，組織型および肝転移との関係について検討した，組織型では，高 分化腺癌 $48.7 \%$, 中分化腺癌 $29.3 \%$, 低分化腺癌7.2\%であり，高分化な癌ほど laminin 陽性率は高かっ た。低分化腺癌の陽性 6 例はすべて充実胞巣型であった。肝転移との関係では, laminin 陽性率は肝転 移陰性例 $23.1 \%$ ，肝転移陽性例 $91.3 \%$ ，肝転移巣 $90.9 \%$ と肝転移例ほど laminin 陽性率が高く，低分 化腺癌の肝転移陽性 4 例中 3 例は laminin 陽性の充実胞紧型であった. 以上より, laminin は肝転移を 促進し，従来の組織型と肝転移の関係を lamininの面から解明できることを示唆した。

卖引用語： laminin, 胃癌組織, 免疫組織学的染色 ( $\mathrm{ABC}$ 法), 胃癌肝転移

\section{I.はじめに}

Lamininは分子量82万ダルトンの糖蛋白であり， fibronectin, proteoglycan, entactin, type IV collagen などとともに，基底膜構成成分の 1 つである。最近， 培養細胞を用いた研究で，これらの基底膜成分の質 的・量的変化が癌の浸潤・転移に関与するとして注目 されている(12). 免疫組織化学的研究では, 乳癌 ${ }^{3) 4}$, 甲 状腺癌5)，大腸癌(6) と扣いて基底膜成分の破壊あるいは 消失が，漫潤・転移能の強い癌にみられることを報告 している.これに対し，われわれ》は酵素抗体法による laminin の免疫組織化学的研究を行い, 大腸癌では肝 転移例潘ど laminin 陽性率が高いことを示してきた。 しかし，大腸癌は高・中分化腺癌が大部分を占め，低 分化腺癌や未分化癌は極めて少数であるため, 癌の組 織型, laminin 活性および肝転移の関係について検討

<1989年 9 月19日受理>別刷請求先：松田 泰次 干589 大阪狭山市大野東377-2 近畿大学医学部第 1 外科
することが困難であった。しかす，胃癌組織における laminin の研究に関しては卧とんど行われていな (、8).そこで, 本研究では胃癌組織における lamininの 免疫組織化学的研究を行い, lamininの分布を明らか にするとともに, 組織型技よび肝転移との関係につい て検討した。

\section{II. 対象と方法}

対象症例は1988年までに近畿大学第 1 外科で切除さ れた胃癌214例である。病理学的検討は「胃癌取扱い規 約 」9 に基づいて行った。初回手術時に肝転移を認めな かった症例は187例, 肝転移陽性例27例であった。

切除材料より，1つは病巣の中心を通る少なくとも 3 つの幅 $5 \mathrm{~mm}$ 標本を採取した，標本は直ちに $10 \%$ formalin 液で48時間固定し, paraffin 包埋ブロックを作 成した後, 厚さ $6 \mu \mathrm{m}$ の切片を作成した。脱 paraffin 後, 内因性 peroxidase 活性を阻止するために, methanol 中 $0.3 \%$ 過酸化水素水で 30 分間処理した。各切片は trypsinによって $37^{\circ} \mathrm{C}, 20$ 分間処理した. Trypsin 処理 
図 1 胃高分化腺癌における lamininの局在

a. Laminin 染色陽性：癌腺管基底部に lamnin 染色を認める（×130）. b. Laminin 染色陰性：Laminin 染色は血管壁に見られるが，腺管基底部には認められない（メ 100).

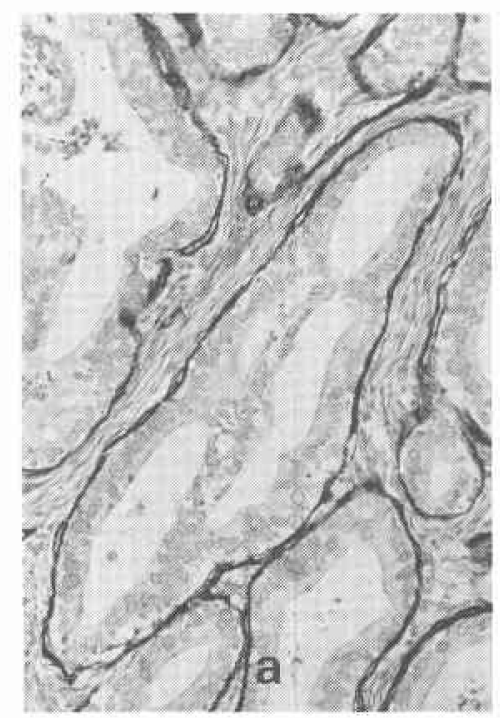

には, 蒸留水に $0.02 \% \mathrm{CaCl}_{2} お$ よび $0.02 \%$ trypsin （DAKO，1：250）を溶解した液（pH 7.80）を用い た。

免疫組織学的染色は Hsu-Ming $(1981)^{10)}$ により開発 された avidin-biotin peroxidase complex 法 (ABC 法)に準じて，以下の操作を行った。（i） $10 \%$ 正常ヤギ 血清（2 次抗体を作成した動物と同種の正常血清）を 滴下，切片を被覆し $37^{\circ} \mathrm{C} ， 10$ 分間反応させ，(ii） 1 次 抗体として燐酸緩衝液 (PBS) で200倍希釈したウサギ 抗 laminin 抗体 (CR 社) を用い， $4{ }^{\circ} \mathrm{C} て ゙ 12$ 時間反応さ せた.（iii） 2 次抗体は biotin 化 IgG (PBS で200倍希 釈)を用いて，室温，30分間反応させた。続いて，(iv） $\mathrm{ABC}$ キット（Vectastain，VECTOR）を用い, 30分 間室温で反応させた，各操作の終了ごとにPBSで洗 浄した。発色には，0.02\%3,3'-diaminobenzidine (DAB) (和光純薬), $0.005 \% \mathrm{H}_{2} \mathrm{O}_{2}$ を加光た tris-buffer 液を用いた。

Laminin はすべての正常組織の基底膜と血管壁で 陽性に染色された，正常胃上皮基底膜および血管壁に laminin が明瞭に染色された切片に限り適切であると し, 免疫組織学的研究に用いた。本研究では, 癌腺管 上皮基底部抒よび癌巣塊周团（以下に腫湟一間質境界 とする）の laminin 活性のみを評価の対象とした（図 1). Laminin 染色陽性の判定は，われわれわの以前の

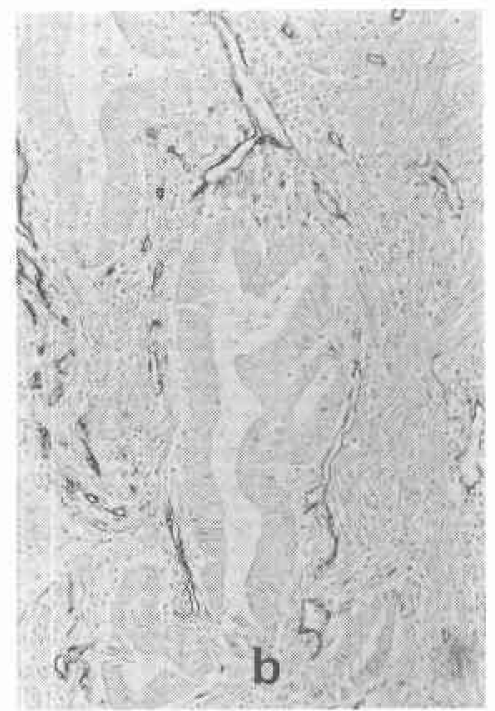

研究結果ならびに Forster の判定規準 11122)参考にし て, 数切片について検索し, laminin 活性が各切片にお ける癌病巣全体の $50 \%$ 以上を占める場合に laminin 陽 性と判定した。

統計処理は, $x^{2}$ 検定を用いて, $\mathrm{p}<0.05$ の場合を有意 差ありと判定した。

\section{III. 結 果}

1. 組織型と laminin 活性

胃癌原発巣の全体の laminin 陽性率は24.3\%（52/ 214)であった。腫瘍一間質境界の laminin 染色と組織 型（分化度）の関係を表 1 に示す。 Laminin 陽性率は 高分化腺癌で $48.7 \%$ (19/39), 中分化腺癌 $29.3 \%$ (27/ 92)，低分化腺癌 $13.3 \%(6 / 45)$ であり，低分化型にな る汪ど有意に laminin 陽性例は低率となった（ $\mathrm{p}<$ 0.01)。京た膠様腺癌と印環細胞癌ではすべて陰性で あった。低分化腺癌に批る laminin の局在様式につ いて詳細に検討するために，低分化腺癌をさらに充実 胞巣型 (solid type), 髄様型 (medullary type), 硬性 型 (scirrhous type) の 3 つに組織学的亜分類した（図

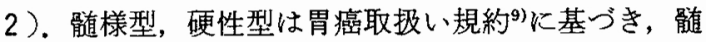
様型は病巣内には結合織が注とんどなく䯣様に増殖し ているもの, 硬性型は線維成分を多く含む間質結合織 の中に単一癌細胞が遊離した状態で増殖するもの, と した。本研究で新しく加えた充害胞巣型は，間質結合 
図 2 低分化腺癌における laminin の局在，充実胞巣型にの及，腫瘍一間質境界に laminin 染色がみられる $(\times 200)$.

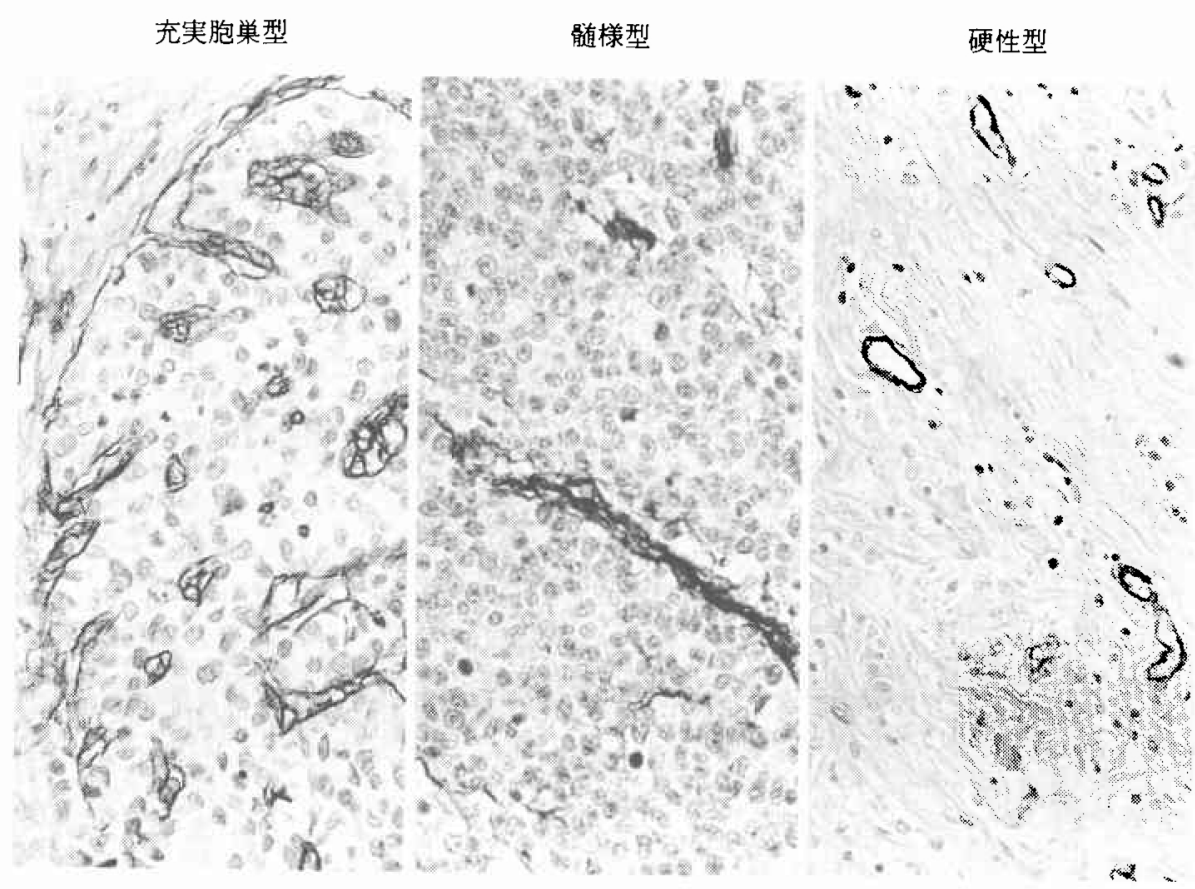

表 1 組織型と laminin 染色性

\begin{tabular}{|c|c|c|}
\hline 組機型 & \multicolumn{2}{|c|}{ laminin 19 性事 (\%) } \\
\hline 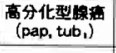 & $19 / 39$ & (48.7\%) \\
\hline 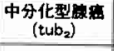 & $27 / 92$ & (29.3\%) \\
\hline 低分化眼艘 & $6 / 45$ & (13.3\%) \\
\hline 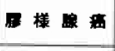 & $0 / 21$ & $\left(\begin{array}{ll}0 & \%\end{array}\right)$ \\
\hline 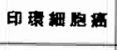 & $0 / 13$ & $\left(\begin{array}{ll}0 & \%\end{array}\right)$ \\
\hline 特 殊 型 & $0 / 4$ & $\left(\begin{array}{ll}0 & \%\end{array}\right)$ \\
\hline
\end{tabular}

織中に比較的膨張性に発育したいくつかの癌巣塊が島 状に存在するものとした。低分化腺癌の laminin 陽性 6 例はすべて充実胞巣型であった(表 2$)$ ．充実胞巣型 に抢ける laminin の局在は, 数個以上の癌細胞塊を取 り囲さように線状にみられた。しかし，髄様型，硬性 型では腫瘍間質境界にも, 癌細胞質にも認められな かった（図 2).

2. 壁深達度と laminin 染色

癌の壁深達度を固有筋層までにとどするもの (pm 以下）と，固有笳層を貫くもの（ss 以上）とに分類し た. pm 以下の laminin 陽性率は $17.4 \%$, ss 以上では $26.2 \%$, 壁深達度と laminin 陽性率の間には相関が
表 2 低分化腺癌の亜分類と laminin 染色性

\begin{tabular}{|c|c|c|c|}
\hline & & 型 & Jaminin雺性率 \\
\hline \multicolumn{3}{|c|}{ 充実胞型 } & $6 / 6(100 \%$ \\
\hline 䤄 & 傣 & 型 & $0 / 23 \quad(0 \%)$ \\
\hline 屚 & 性 & 型 & $0 / 16 \quad(0 \%)$ \\
\hline
\end{tabular}

表 3 壁深達度と laminin 染色性

\begin{tabular}{|c|c|c|}
\hline & laminir用性例 / 全例 & (\%) \\
\hline$\sim \mathrm{pm}$ & $8 / 46$ & $(17.4 \%)$ \\
\hline ss & $44 / 168$ & $(26.2 \%)$ \\
\hline
\end{tabular}

みられなかった（表 3 ).

3. 肝転移と laminin 染色性

肝転移陰性の胃癌原発巣之肝転移陽性の原発巣の laminin 陽性率を比較した（表 4 ）。高・中分化腺癌で は肝転移陰性群原発巣の laminin 陽性率は23.1\%(25/ 108)であるのに対して，肝転移例の原発巣では $91.3 \%$ (21/23), 肝転移巣では $90.9 \%(10 / 11)$ であり, 肝転 移例ほど laminin 陽性率は有意に高率であった（ $<<$ 0.001)（表 4, 図 3)。低分化腺癌でも同様の傾向がみ られたが, 肝転移陽性例 4 例のうち 3 例までが 
組織型別にみた肝転移と laminin 染色性の比 較

\begin{tabular}{|c|c|c|c|}
\hline tamminn & 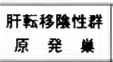 & 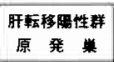 & 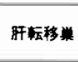 \\
\hline 高·中分化型睏瘘 & $\begin{array}{l}25 / 108 \\
(23.1 \%)\end{array}$ & $\begin{array}{l}21 / 23 \\
(91.3 \%)\end{array}$ & $\begin{array}{l}10 / 11 \\
(90.9 \%)\end{array}$ \\
\hline 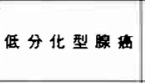 & $\begin{array}{l}3 * / 79 \\
(3.8 \%)\end{array}$ & $\begin{array}{c}3 * / 4 \\
(75.0 \%)\end{array}$ & $\begin{array}{c}1 * / 1^{*} \\
(100 \%)\end{array}$ \\
\hline total & $\begin{array}{l}28 / 187 \\
(15.0 \%)\end{array}$ & $\begin{array}{l}24 / 27 \\
(88.9 \%)\end{array}$ & $\begin{array}{l}11 / 12 \\
(91.7 \%)\end{array}$ \\
\hline
\end{tabular}

図 3 高分化腺癌の肝転移栄に括壮る lamininの局 在 $(\times 400)$

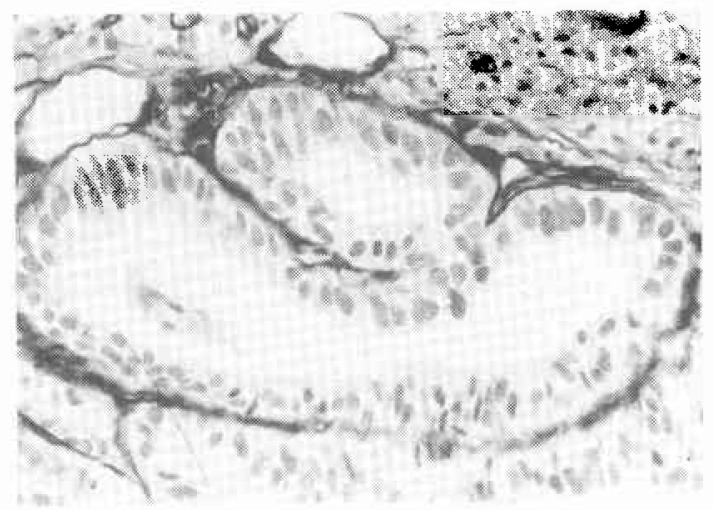

図 4 低分化腺癌充実胞巣型の肝転移巣における laminin の局在 $(\times 400)$

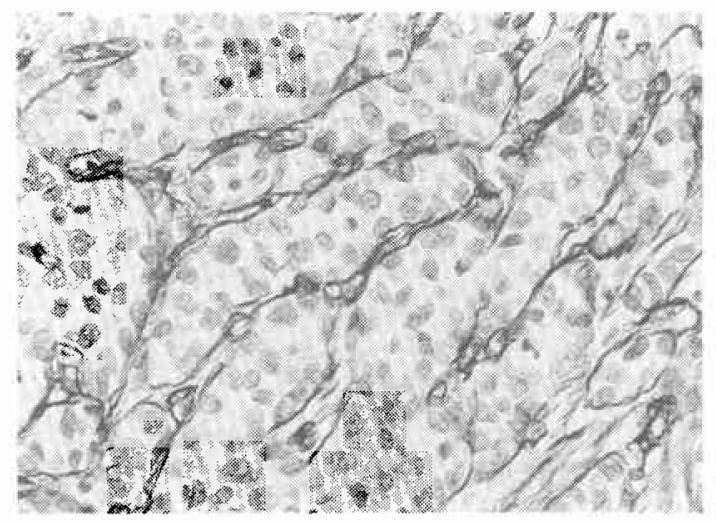

laminin 陽性例であり，この 3 例はすべて充実胞巣型 であった(表 4)。低分化腺癌の肝転移巣は 1 例のみし か検索していないが，充実胞巣型で数個の癌細胞塊の 周囲の腫瘍一間質境界に陽性染色がみられた（図 4 ）.

\section{IV，考察}

最近の培養細胞を用いた研究 ${ }^{122}$ では，基底膜を構成 している laminin や fibronectinは接着能をるった glycoprotein で，この消失が浸潤さらには転移に影響 することが報告されてきている。しかし, lamininの組 織学的研究に関しては, 現在までのところ十分ではな

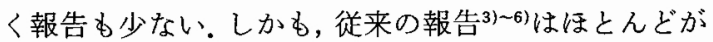
fibronectin と同様, 癌の進行とともに laminin が消失 し，癌の浸潤が起こるとする報告である。たと光ば， Burtin ${ }^{61}$ は営光抗体法によって, 大腸癌の辺縁部では laminin が汪とんど完全に消失していることから， laminin 消失例汪よ゙浸潤しやすいとしている。その後， Forster ら ${ }^{1112)}$ 住酵素抗体法によって, 癌腺管基底部 の laminin 染色が遠隔転移と正の相関があり, laminin 染色性の低下した癌注ぞ肝転移を起こしやすいと報告 している。しかしながら，今回のわれわれの研究結果 は, Forster らの報告と大きく異なることを示した。わ れわれは癌の肝転移と laminin の関係を検討するため には，肝転移巣に怙ける laminin の局在を検索するこ とが重要であると考光た。この結果，手術時に肝転移 のない胃癌の laminin 陽性率は $15.0 \%$ であるのに対 し, 肝転移を有する胃癌の陽性率は $88.9 \%$, 肝転移巣 は91.7\%であり, laminin 陽性の腫瘍注ど肝転移率が 高いことを示した。 Terranova ら ${ }^{13144}$ は in vitroで好 転移細胞株と低転移細胞株の type IV collagen に対 する接着について検討した結果, laminin が転移過程 のうら, 腫瘍細胞の基底膜への接着を促進することを 示唆した。 Liotta $5^{15) 16)}$ 为様に培養細胞を用いた laminin の生化学的測定により, laminin の存在が転移 を促進することを報告した。これらの結果は, laminin 陽性の癌細胞が転移しやすいという本研究結果に一致 すると考学られる。しか，転移の第 1 段階では基底 膜の破壊が重要であり，基底膜構成成分である laminin も消失する必要があるのではないかとい5反 論(1) 6) む多い. Liotta ${ }^{16)}$ の提唱した'three step hypothesis'は癌の基底膜破壊（=浸潤）と着床（二転移）とい ら一見相反する現象を矛盾なく，一連の過程として説 明している。すなおち，基底膜の組織構築に関しては type IV collagenが重要な役割をになっており, 癌が 浸潤する際にはこの強固な collagen network を破壊 する matrix 分解物質を癌細胞自体が分泌することが 必要である。この matrix 分解物質には plasminogen activator, cathepsin B 拉よび各種の collagenase が あるが, type IV-collagen を特異的に分解する type 
IV collagenase が特に重要である。これら matrix 分 解物質とくに type IV collagenase の癌細胞よりの分 泌は, 癌細胞膜表面に存在する laminin receptor $に$ laminin が結合することにより起こるとされている. したがって, 原発巣周囲組織への癌細胞浸潤には laminin が関与し, 浸潤した癌細胞にはむしろ laminin が結合していると想像される。そして, 標的葴器では, 癌細胞に結合した laminin が接着剂として標的缄器内 の脈管基底膜への接着を促進し，その後は原発巣での 過程を繰り返し, 標的蔵器の組織内一浸潤するという 考方方である。この Liotta ${ }^{16)}$ の仮説を正確に理解する ならば， laminin 陽性例が肝転移を来しにくいとする Forster ら ${ }^{1112)}$ の結果は矛盾があり, むしろ, 転移が認 められる時点では, 原発巣の他の多くの癌細胞の receptorにも laminin が結合していると考学る方が妥当 であり，本研究結果の方が合理性があると考学る。

本研究のも51つの目的は, 組織型と laminin の関 係を検討することであった，組織型別に laminin 陽性 率をみると，高分化腺癌で $48.7 \%$ であるのに対し，低 分化腺癌では7.2\%と，分化度が低いもの汪ど laminin 陽性率子低下した。これは諸家の大腸癌6)12) や乳癌334 における研究結果と一致した。しかし, 本研究では胃 癌を対象とすることによって，大腸癌に比べより多く の低分化腺癌を検討することが可能となった，われわ れは低分化腺癌を従来の髄様型, 硬性型に充実胞巣型 を加觉て，3つに分類した結果, 浸潤度の低い比較的 膨張性増殖を示す充実胞巣型に laminin 陽性率が高 かった，以上のことから，分化度の高いものほど，低 分化腺癌では浸潤度の低い充実胞巣型に laminin 陽性 例が多いことが判明した。

組織型と肝転移に関しては，一般に分化型ほど肝転

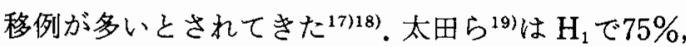
$\mathrm{H}_{2}$ で $90 \%$ が分化型であったとしている，一方，渡辺 $ら^{20)}$ は動物実験により，血行性転移は単一細胞ではな く細胞群により形成されるとし, 長尾ら おける胃癌の血管侵襲と血行性転移について検討し， 小静脈系侵襲では数十個以下, 中静脈系侵襲では数百 個以上が癌細胞塊を形成していることが大多数である ことより，細胞群が血行性転移を起こしやすいとして いる，安富ら ${ }^{22)}$ は以上の報告と自験例の検討を踏を兄 て，高分化型が低分化型に比べ肝転移を来しやすいの は，細胞群を形成するからであると指摘している。 た曽和 $5^{23)}$ ，木村 $5^{24)}$ ，高橋ら ${ }^{25}$ は，低分化腺癌でも䯣 様型增殖をとる症例では肝転移陽性例が多いことを示
唆している、本研究では, 従来おをらく葡様型の範ちゅ らに入れられていたと考える充実胞巣型に肝転移例が 多いことが判明した。しかも，充実胞巣型は原発巣の laminin が陽性であるばかりでなく，静脈内に侵襲し た癌紐胞も塊状形成をし，その周囲に laminin が存在 していた，以上のことから，高分化型，低分化型を問 わず, laminin 陽性のものは塊状形成しやすくこのこ とが laminin 陽性例活ど肝転移を起こしやすいもう 1 つの理由ではないかと考克た，それとともに，従来の 肝転移々組織型の関係を laminin の面から裏打ちでき ると考㝋る。

壁深達度と laminin に関しては, Forster ら ${ }^{1112)}$ 壁深達度の深いものほど laminin 陽性例が多い傾向を 示しているが，本研究結果では壁樑達度と laminin 陽 性率は相関しなかった。いいかえれば, laminin は血行 性転移の予測に関しては壁深達度とは別の因子である と考党る。

以上, 胃癌組織に拈ける laminin の免度組䅧学的研 究を行い，胃癌肝転移と lamininの関係を中心に述へ た。さらに type IV collagen やその他の基底膜構成成 分，あるいは matrix 分解醭素についての研究が必要 であることが考市られるが，しかし，従来の報告にな $く$, laminin 染色性が肝転移々密接に関係し, laminin 陽性の癌ほど肝転移を来しやすいことを示すととも に, 癌の組織型と血行性転移の関係を laminin 活性か ら解明できることを示唆した。

\section{文 献}

1) Kleinman HK, Klebe RJ, Martin GR: Role of collagenous matrix in the adhesion and growth of cells. J Cell Biol 88 : 473-482, 1981

2) Woodly DT, Liotta LA, Martin GR et al: Interaction of basement components. Biochem Biophys Acta 761 : 278-283, 1983

3) Siegel G, Terranova VP, Liotta LA et al: Stages of neoplastic transformation of human breast tissue as monitored by dissolution of basement membrane component. Invasion Metastasis 1:54-65, 1981

4) Barsky SH, Siegel G, Liotta LA et al: Loss of basement membrane components by invasive tumors but not by their benign counterparts. Lab Invest 49 : 140-148, 1983

5) Kendall $C$, Sanderson $P$, Talbot $U$ et al : Follicular thyroid tumors: A study of laminin and type IV collagen in basement membrane endothelium. J Clin Pathol 38 : 1100-1105, 1985

6) Burtin P, Foidart JM, Martin E et al: 
Antigens of the basement membrane and the peritumoral stroma in human colonic adenocarcinomas: An immunofluorescence study. Int $\mathrm{J}$ Cancer $30: 13-20,1982$

7) 松田泰次：大腸癌の免疫組織学的検討からみた癌 の漫潤・転移におけるラミニンの役割。医のあゆみ $141: 194,1987$

8) Grigioni WF, Biagini G, Errico $A D$ et al : Behaviour of basement membrane antigens in gastric and colorectal cancer: Immunohistochemical study. Acta Pathol Jpn $36: 173-184$, 1986

9）胃癌研究会編：胃癌取扱い規約. 第11版。東京, 金 原出版, 1985

10) Hsu SM, Ralne L, Fanger $H$ : The use of antiavidin antibody and avidin-viotin peroxidase complex in immunoperoxidase technique. Am J Clin Pathol 75:816-821, 1981

11) Forster SJ, Talbot IC, Claiton DC et al: Tumor basement membrane laminin in adenocarcinoma of rectum: An immunohistochemical study of biological and clinical significance. Int J Cancer 37 : 813-817, 1986

12) Forster SJ, Talbot IC: Laminin and fibronectin in rectal adenocarcinoma : Relation. ship to tumor grade, stage and metastasis. $\mathrm{Br} \mathrm{J}$ Cancer $50: 51-61,1984$

13) Terranova VP, Hujanen ES, Martin GR et al : Use of a reconstituted basement membrane to measure cell invasiveness and select for highly invasive tumor cells. Proc Natl Acad Sci USA 83:465-469, 1986

14) Terranova VP, Martin GR, Kleinman $\mathrm{H}$ et al : Regulation of cell attachment and cell number by fibronectin and laminin. J Cell Physiol 127 :
473-479, 1986

15) Liotta LA, Rao CN, Barsky SH: Tumor invasion and the extracellular matrix. Lab Invest $49: 636-649,1983$

16) Liotta LA : Tumor invasion and metastasisrole of the extracellular matrix. Cancer Res $46: 1-7,1986$

17) 西 満正, 田村竜男, 高月英夫：肝転移胃癌の臨床 病理学的研究一とくに肝転移成立の条件因子につ いて一. 癌の臨 8:759-767, 1962

18）橋本 謙, 掛川暉夫, 武田仁良ほか：肝転移を有す る胃癌に対する臨床的検討。日消外会誌 19 ： $752-756,1986$

19）太田博俊, 高木国夫：胃癌肝転移例の検討。消外 $4: 999-1004,1981$

20) Watanabe $S$ : The metastasizability of tumor cells. Cancer $7: 215-223,1954$

21）長尾孝一, 松部 理, 井出源四郎：胃澏の血管侵氈 と畽汮塞栓形成について一剖検例における血行性 肝転移症例を中心にして一. 癌の臨 $21: 148$ $-153,1975$

22）安富正幸, 丸山次郎, 松田泰次ほか：転移性肝癌の 治療と予後. 外科 $45: 137-142,1983$

23）兽和融生, 加藤保之, 芳野裕明ほか：肝転移胃癌の 検討一とくに髅様型低分化腺癌と核 DNA との関 連について一. 日消外会誌 $21: 32-37,1988$

24）木村 修, 万木英一, 岡本恒之ほか：肝転移・肝再 発のみられた胃癌の病理組織学的特徽一とくに䯣 様型低分化腺癌について一. 癌の臨 $30: 131$ $-137,1984$

25）高橋 豊, 磨伊正義, 秋本龍一ほか：胃癌の肝転移 high risk 症例の臨床病理学的検討一とくにAFP 産生胃癌との関係について一. 日消外会誌 17 ： $1732-1736,1984$ 